Revista Brasileira de Agricultura Irrigada v.8, nº. 4, p.334 - 342, 2014

ISSN 1982-7679 (On-line)

Fortaleza, CE, INOVAGRI - http://www.inovagri.org.br

DOI: $10.7127 /$ rbai.v8n400183

Protocolo 183/13 - 23/09/2013 Aprovado em 01/07/2014

\title{
CULTIVATION OF YELLOW PEPPERS USING ENERGIZED AND NON- ENERGIZED WATERS AND DIFFERENT DOSES OF BIOFERTILIZERS
}

\author{
Francisca Robevânia Medeiros Borges ${ }^{1}$; Luis Gonzaga Pinheiro Neto ${ }^{2}$; Thales Vinícius \\ de Araújo Viana ${ }^{3}$; Albanise Barbosa Marinho ${ }^{4}$; Benito Moreira Azevedo ${ }^{3}$.
}

\begin{abstract}
This study was aimed at evaluating the production characteristics of the yellow Sunny F1 hybrid pepper irrigated with energized and not energized water and with water with different doses of biofertilizers. The experiment was conducted from August 2010 to December 2010 in the experimental area to the Universidad Federal do Ceará (UFC) in Fortaleza, Ceará $(\mathrm{Br})$. The experimental design was the randomized blocks with four replications, set up as split plots, with plots irrigated with differently treated water (energized and not energized) and the subplots irrigated with water containing different dosages of biofertilizer $\left(0,400,800,1200\right.$ and $1600 \mathrm{~L} \mathrm{ha}^{-1}$ week $\left.^{-1}\right)$. The energizing process is done using an equipment called Aquatron ${ }^{\circledR}$, programmed according to the chemical and physical properties of the water, used specifically for physiological benefits for plants and past and diseases control. The experiment was conducted in pots with 40L capacity, with four plants per treatment. We evaluated the following production characteristics: soluble solids, length, diameter, average fruit weight, flesh thickness, number of fruits and total yield. Based on the results and on the conditions under which the study was performed, we concluded that: The energizing water treatment did not cause significant changes to the cultivation of peppers under ideal irrigation conditions. The biofertilizer was not enough to adequately fertilize the crop, even in the larger dosages applied, demanding supplementation with mineral fertilizer or dosage increase.
\end{abstract}

Keywords: Capsicum annuит L., biofertigation, water treatment, organic fertilizer

\footnotetext{
${ }^{1}$ Tecnóloga em Irrigação e Drenagem, Doutoranda Engenharia Agrícola UFC -, Bloco 804, Av. Mister Hull s/n, 60450-760 Fortaleza-CE. Email: robevania_b@hotmail.com

${ }^{2}$ Prof. Dr. IFCE - Campus Sobral. Email: luis.neto@ifce.edu.br

${ }^{3}$ Prof. Dr. UFC Engenharia Agrícola UFC, - Bloco 804, Av. Mister Hull s/n, 60450-760. Fortaleza-CE. . Email: thales@ufc.com.br; benitoazevedo@hotmail.com

${ }^{4}$ Profa. Dra. UNILAB. Email: albanise@unilab.edu.br
} 


\title{
CULTIVO DO PIMENTÃo AMARELO COM ÁGUAS ENERGIZADA E NÃO ENERGIZADA E COM DOSES DE BIOFERTILIZANTE
}

\begin{abstract}
RESUMO
O presente trabalho foi conduzido com o objetivo de avaliar as características de produção do pimentão híbrido amarelo irrigado com águas energizada e não energizada e com diferentes doses de biofertilizante. O experimento foi realizado entre agosto a dezembro de 2010 na área experimental da Universidade Federal do Ceará (UFC), em Fortaleza. O delineamento experimental foi blocos ao acaso, com quatro repetições, instalado em parcelas subdivididas, sendo as parcelas constituídas pelos tratamentos irrigação com água energizada e não energizada e as subparcelas por 5 doses de biofertilizante $\left(0,400,800,1200\right.$ e $1600 \mathrm{~L} \mathrm{ha}^{-1}$ semana $\left.^{-1}\right)$ aplicadas via água de irrigação. $O$ processo de energização da água se dá através da utilização de um aparelho denominado Aquatron ${ }^{\circledR}$, programado de acordo com as propriedades físico-químicas da água, de uso específico para benefícios fisiológicos das plantas e controle de pragas e doenças. O experimento foi conduzido em vasos com volume de $40 \mathrm{~L}$, com quatro plantas por tratamento. Foram avaliadas as seguintes características de produção: sólidos solúveis, comprimento, diâmetro, peso médio do fruto, espessura da polpa, número de frutos e produção total. Com base nos resultados apresentados e nas condições nas quais foram realizadas o estudo, concluíram-se que: o tratamento da água por energização não possibilita alterações significativas no cultivo do pimentão sob condições hídricas ideais; o biofertilizante não foi suficiente para fertilizar adequadamente a cultura, mesmo nas maiores quantidades utilizadas, fazendo-se necessário uma suplementação com adubação mineral ou elevação de suas dosagens.
\end{abstract}

Palavras - chave: Capsicum annuum L., biofertirrigação, tratamento de água, fertilização orgânica.

\section{INTRODUCTION}

Organic agriculture is a production system committed to the health, ethics and citizenship of human beings (PENTEADO, 2004). It seeks to use natural resources rationally, by employing traditional agricultural methods and the latest green technology, as well as by eliminating the use of pesticides and synthetic fertilizers that can be harmful to human health and the environment.

The demand for organically grown sweet peppers has been rising, in response to frequent disclosure by the media of product contamination by pesticide residues (ANVISA,
2009). Thus, the production of organic sweet peppers is both an excellent business opportunity and a considerable challenge for producers.

In this search for sustainability, water is an essential factor in agriculture, requiring new technologies for better usage (CHARLO et al., 2009), as well as a more rational use of this resource, such as that offered by the energizing process performed by the Aquatron ${ }^{\circledR}$ system. According to the manufacturer, this equipment is programmed based on the physicochemical properties of water, with specific use for obtaining greater physiological benefits to 
plants, as well as in assisting in pest and disease control. During the passage of water through the system, the controller sends electromagnetic signals to the electrodes installed inside the energy chamber, converting these signals into ULF (Ultra Low Frequency) waves. These waves and the electrons change the structure of the water molecule (normally polygonal) into a more linear structure, thus breaking its surface tension. In this manner, they alter the natural surface charge of suspended particles, facilitating absorption, reducing water consumption, and improving the bioavailability of nutrients in the soil solution for the plant (AQUATRON, 2008).

The equipment is installed within the irrigation pipes, in order to treat all the water that passes through the system. According to some producers, the yield of pepper crops can increase by $38 \%$, with a $17 \%$ gain in plant height, as well as fruit weight augmented by up to $7 \%$ (AQUATRON, 2008).

To meet a sustainable development model, the family farmer, who usually does not own much resource to buy synthetic inputs, has been making use of organic fertilizers formed from compounds recovered in his farm. The use of biofertilizers has grown among family farmers, as these resources are a cheap alternative for vegetable cultivation in lieu of conventional inputs.

According to Araújo (2008), biofertilizers are biodynamic and biologically active compounds produced in biodigesters by means of aerobic and/or anaerobic fermentation of organic matter. These compounds are rich in enzymes, antibiotics, vitamins, toxins, phenols, esters, and acids, including those with phytohormonal activity. They also contain macro- and micronutrients that vegetables can easily assimilate, such as nitrogen, phosphorus, potassium, calcium, magnesium, sulfur, sodium, iron, chlorine, silicon, molybdenum, boron, copper, zinc and manganese.

Ribeiro et al. (2000), while studying organic fertilizer in sweet peppers cv. 'National AG 506', found significant increases in average fruit weight when organic and organic + minerals sources were used, especially organomineral fertilizer combined with vermicompost + chemical fertilizer. Important results regarding changes in the number of fruits were also observed by Araújo et al. (2003) while testing both organic and organomineral solutions for sweet peppers. No significant difference between the nutrient solutions used was observed.

Therefore, sweet pepper production characteristics are influenced by, among other factors, management of fertilizer and water. With this in mind, the aim of this work was to evaluate the effects of untreated water and water treated by energization, as well as those of different biofertilizer doses on organic cultivation of yellow peppers.

\section{MATERIALS AND METHODS}

The study was conducted in the experimental area of the Agro Weather Station belonging to the Universidade Federal do Ceará (UFC), Fortaleza $\left(03^{\circ} 44^{\prime} \mathrm{S}, 38^{\circ} 33^{\prime} \mathrm{W}, 19.5\right.$ m), from August to December 2010. 
The experimental design was that of randomized blocs with four repetitions, installed in split portions, due to the energizing system distribuition in field, each portion consisting of energized and non-energized water treatments with subplots of 5 doses of biofertilizers $(0,400,800,1200$ and $1600 \mathrm{~L}$ ha ${ }^{1}$ week $^{-1}$ ) applied via the irrigation water.

The water energizing treatment was performed by the Aquatron ${ }^{\circledR}$ Green Machine equipment. As the system is set on an abundant level of electrons is released which in turn increases the voltage of physiological processes, the energy level in soil is amplified and microbiological communities are stimulated causing a more effective availability of nutrients for plant growth. The energy measuring unity should be kept above 100 and below 450, and the best operation band reading is between 180-270. The UBF wave signals are within 300 and $3.000 \mathrm{~Hz}$ range.

The biofertilizer was produced at the experimental Station in a container with a mechanical stirrer, using $250 \mathrm{~L}$ of bovine manure, $120 \mathrm{~L}$ of water, $2.8 \mathrm{~L}$ of cow's milk, PT-4-O $®$ (accelerator), bone meal, stone powder, as well as ingredients to accelerate the metabolism of bacteria. The biofertilizer had the following characteristics: N, P, K, Ca and $\mathrm{Mg}\left(\mathrm{g} \mathrm{L}^{-1}\right): 0.2, \quad 0.1,0.8,4.3$ and 0.7 , respectively.

The seeds were sown on Aug 1, 2010, in expanded polystyrene trays of 128 cells, each containing experimentally-produced substrate composed of vermiculite and biofertilizer, using yellow pepper cultivar 'Sunny F1'. The seedlings were transplanted into 40 -liter pots, using substrate containing one part manure, one part sand and three parts of local soil, been classified as yellow-red Argisoil (EMBRAPA, 2006) at 28 DAP (days after planting), when emitting three to four pairs of definitive leaves. The chemical properties of the substratum before the treatment aplication are presented in the table 1 below.

Table 1 - Values of the chemical analysis of the experimental area of the substrate, in the 0 to $0.2 \mathrm{~m}$, Fortaleza, Ceará, 2010.

Chemical characteristics of the substrate of the experimental area

\begin{tabular}{cccccccccc}
\hline & $\begin{array}{c}\mathrm{mg} \\
\mathrm{kg}^{-1}\end{array}$ & \multicolumn{4}{c}{$\begin{array}{c}\text { Cmolc } \\
\mathrm{kg}^{-1}\end{array}$} & & & \multicolumn{1}{c}{$\begin{array}{c}\mathrm{dS} \\
\mathrm{m}^{-1}\end{array}$} & $\%$ \\
\hline $\mathrm{pH}$ & $\mathrm{P}$ & $\mathrm{K}$ & $\mathrm{Ca}$ & $\mathrm{Mg}$ & $\mathrm{Na}$ & $\mathrm{Al}$ & $\mathrm{H}+\mathrm{Al}$ & $\mathrm{CE}$ & $\mathrm{PST}$ \\
\hline 6.7 & 68 & 0.37 & 2.70 & 2.60 & 0.30 & 0.10 & 0.99 & 1.03 & 4 \\
\hline
\end{tabular}

Source: Laboratory of Soil and Water for Irrigation, IFCE Limoeiro do Norte.

The irrigation system used was a drip system consisting of a line of emitters for each plant row, with one emitter per plant, maintaining an average flow rate of $8 \mathrm{~L} \mathrm{~h}^{-1}$ per emitter. The water was supplied daily, and irrigation time was calculated from the avarage evaporation in the class "A" tank, while attempting to keep the soil at field capacity, so as not to cause water stress in the crop. Te criteria adopted to calculate the irrigation time were: Pan coefficient $\mathrm{Kp}$ of 0,85 , Plant coefficient $\mathrm{Kc}$ as function of number of days after transplantation (ALLEN et. al, 1998); 
vase area $\left(0,096 \mathrm{~m}^{2}\right)$; soil cover factor of 0,8 and irrigation efficiency of $85 \%$.

Throughout the experimental work, crop handling followed the recommendations made for pepper-growing, using sticks and ribbon for tying, according to their stage of development. Pest control was carried out with products allowed in organic farming, such as solutions based on wheat flour, cashew nut extract and alcohol, and products with Indian neem as an active principle.

Harvest of the fruit began on the 100th day after seedling transplant, when the plants displayed an approximately $70 \%$ yellowed surface. The fruits were collected and taken to the laboratory where the following characteristics were assessed: total fruit yield, number of fruits per plant, average weight, length, longitudinal diameter, total soluble solids and pulp thickness. In order to determine the overall productivity, yield per plant and the estimated number of plants per hectare $(20,000$ plants) were taken into account. Statistical analysis of data was performed using the Sisvar program, from Universidade Federal de Lavras (FERREIRA, 2000).

\section{RESULTS AND DISCUSSION}

According to the summary of the analyses of variance presented in Table 2, doses of biofertilizer associated with the use of energized water did not exert significant effects at $1 \%$ and $5 \%$ on the variables soluble solids (SS), fruit length (FL), fruit diameter (FD), average fruit weight (FW), flesh thickness (PS), number of fruits (NF) and total yield (TY). There was no significance in the interaction of biofertilizer versus energized water.

Table 2. Summary of analysis of variance and regression of soluble solids (SS), fruit length $(\mathrm{FL})$, fruit diameter $(\mathrm{FD})$, fruit weight $(\mathrm{FW})$, flesh thickness (PS), number of fruits (NF) and total yield (TY). Fortaleza, Ceará, 2010.

\begin{tabular}{|c|c|c|c|c|c|c|c|c|}
\hline \multirow[b]{2}{*}{ FV } & \multicolumn{8}{|c|}{ F calculated } \\
\hline & Gl & $\begin{array}{c}\text { SS } \\
\left({ }^{\circ} \text { brix }\right)\end{array}$ & $\begin{array}{c}\text { FL } \\
(\mathbf{c m})\end{array}$ & $\begin{array}{c}\text { FD } \\
(\mathbf{c m})\end{array}$ & $\begin{array}{c}\text { FW } \\
(\mathrm{g})\end{array}$ & $\begin{array}{c}\text { PS } \\
(\mathbf{c m})\end{array}$ & $\mathbf{N F}$ & $\begin{array}{c}\text { TY } \\
(\mathbf{k g} \\
\left.\mathbf{h a}^{-1}\right)\end{array}$ \\
\hline Blocks & 3 & $0.89^{\mathrm{ns}}$ & $6.35^{\mathrm{ns}}$ & $3.47^{\mathrm{ns}}$ & $0.26^{\mathrm{ns}}$ & $2.37^{\mathrm{ns}}$ & $0.35^{\mathrm{ns}}$ & $0.49^{\text {ns }}$ \\
\hline Aquatron & 1 & $0.12^{\mathrm{ns}}$ & $4.29^{\mathrm{ns}}$ & $0.06^{\mathrm{ns}}$ & $2.05^{\mathrm{ns}}$ & $0.77^{\mathrm{ns}}$ & $0.62^{\mathrm{ns}}$ & $7.83^{\text {ns }}$ \\
\hline Residual (a) & 3 & - & - & - & - & - & - & - \\
\hline Biofertilizer & 4 & $1.61^{\mathrm{ns}}$ & $0.32^{\mathrm{ns}}$ & $0.27^{\mathrm{ns}}$ & $1.12^{\mathrm{ns}}$ & $0.96^{\mathrm{ns}}$ & $0.33^{\mathrm{ns}}$ & $1.69^{\mathrm{ns}}$ \\
\hline Residual(b) & 24 & - & - & - & - & - & - & - \\
\hline $\mathrm{CV}(\mathrm{a})(\%)$ & - & 14.04 & 3.03 & 7.57 & 30.12 & 17.56 & 57.10 & 41.16 \\
\hline CV(b) (\%) & & 9.70 & 13.16 & 11.04 & 26.98 & 19.63 & 33.86 & 29.95 \\
\hline
\end{tabular}

$\mathrm{FV}=$ source of variation, $\mathrm{ns}=$ not significant by $\mathrm{F}$ test at $5 \%$, * significant at $5 \%$ probability.

The averaged values for the analyzed variables as function of treatments are found in Table 3 For the SS, fruit length, fruit weight, number of fruits and yield variables, it was observed that, despite the fact that the use of energized water showed no statistical differences in relation to irrigation with nonenergized water, the mean values proved to be superior to those of non-energized water. Only the mean values for the variables fruit diameter and flesh thickness were greater for those of the 
energized water, in spite of no statistical difference having been found for either.

Table 3. Average values of soluble solids (SS), fruit length(FL), fruit diameter (FD), fruit weight (FW), flesh thickness(PS), number of fruits (NF) and total yield (TY). Fortaleza, Ceará, 2010).

\begin{tabular}{|c|c|c|c|c|c|c|c|}
\hline $\begin{array}{c}\text { Water } \\
\text { treatment }\end{array}$ & $\begin{array}{c}\text { SS } \\
\left({ }^{\circ} \text { brix }\right)\end{array}$ & $\begin{array}{l}\mathrm{FL} \\
(\mathrm{cm})\end{array}$ & $\begin{array}{l}\text { FD } \\
(\mathrm{cm})\end{array}$ & $\begin{array}{l}\text { FW } \\
(\mathrm{g})\end{array}$ & $\begin{array}{l}\text { PS } \\
(\mathrm{cm})\end{array}$ & $\mathrm{NF}$ & $\begin{array}{c}\text { TY } \\
\left(\mathrm{kg} \mathrm{ha}^{-1}\right)\end{array}$ \\
\hline $\begin{array}{c}\text { Water } \\
\text { energizing }\end{array}$ & 9.55 & 6.97 & 4.15 & 37.63 & 3.15 & 1.40 & 1053.50 \\
\hline $\begin{array}{l}\text { Water non- } \\
\text { energizing }\end{array}$ & 9.70 & 7.12 & 4.14 & 43.15 & 3.00 & 1.65 & 1427.15 \\
\hline Average & 9.62 & 7.05 & 4.15 & 40.40 & 3.07 & 1.52 & 1240.32 \\
\hline \multicolumn{8}{|l|}{$\begin{array}{l}\text { Biofertilizer } \\
\left(\mathrm{L} \mathrm{ha}^{-1}\right. \\
\left.\text { Week }^{-1}\right)\end{array}$} \\
\hline 0 & 10.12 & 6.96 & 4.03 & 37.25 & 3.25 & 1.37 & 1052.00 \\
\hline 400 & 9.87 & 6.94 & 4.23 & 41.37 & 2.75 & 1.75 & 1461.75 \\
\hline 800 & 9.62 & 7.36 & 4.08 & 38.25 & 3.00 & 1.75 & 1375.50 \\
\hline 1200 & 9.00 & 7.09 & 4.21 & 47.12 & 3.12 & 1.37 & 1260.00 \\
\hline 1600 & 9.50 & 6.89 & 4.18 & 37.96 & 3.25 & 1.37 & 1052.37 \\
\hline Average & 9.62 & 7.05 & 4.15 & 40.40 & 3.07 & 1.52 & 1240.32 \\
\hline
\end{tabular}

In the water energizing treatment there was no higher tendency for utilization regarding the experiment conditions. One possible explanation for this is that, according to the manufacturer, treatment by energization proves to be efficient due to greater absorption of water and nutrients. However, considering that in this research the matric potential remained close that of field capacity conditions, it is possible that the energizing treatment does not allow significant changes on the absorption of water and nutrients under such conditions.

The biofertilezer doses used in this work averaged $800 \mathrm{~L} \mathrm{ha}^{-1}$ week $^{-1}$ as recommended by regional extension service and had no significant difference in the studied conditions. Similarly, while testing the effects of different types and dosages of biofertilizers on passion fruit tree growth, Collard et al. (2001) found that bovine biofertilizer had no significant influence on the number of fruits per plant. It can be concluded that the biofertilizer was not sufficient to fertilize the plants, hence there is a need for mineral supplements or higher fertilizer doses.

In relation to the SS variable quality, the control had higher ${ }^{\circ}$ Brix (10.12 ${ }^{\circ}$ Brix), exceeding the values for applied doses by $11.11 \%$. A similar situation was observed by Freire et al. (2010), when evaluating the internal and external attributes of yellow passion fruits grown in lysimeters irrigated with nonsaline and saline waters and using bovine biofertilizer and mulch. The authors found the highest ${ }^{\circ}$ Brix mean values in plant treatments using good-quality water in pits without biofertilizer, revealing an increase of $18.1 \%$ compared those using biofertilizers.

Antoniali et al. (2007), while evaluating the potential for postharvest conservation of yellow peppers 'Zarco HS' in various degrees of maturation, obtained $7.45^{\circ}$ Brix for $75 \%$ yellow coloring and $7.93{ }^{\circ}$ Brix for $100 \%$ yellow coloring. Factor et al. (2008) found mean changes from 6.59 to $7.52{ }^{\circ}$ Brix. Both studies showed lower values than those found in the present study, which displayed an average of $9.62{ }^{\circ}$ Brix. According to Grierson and Kader (1986), a higher fruit ${ }^{\circ}$ Brix initially suggests better flavor.

For production variables in which no significant effect occured, it was observed that 
T3 dosage (1,200 $\mathrm{L} \mathrm{ha}^{-1}$ week $\left.^{-1}\right)$ yielded the highest fruit weight (47.12 g); however, there was no increase in the results presented for production variables at higher dosages. Similar results were found by Sousa et al. (2009), who noticed no significant effects of different concentrations of biofertilizer and application ranges on the growth and yield of sweet peppers.

These results may be explained by a deficiency in fertilization. According to Filgueira (2000), the provision of inadequate doses of nitrogen hinders vegetative growth, reduces photosynthetic area and lowers production potential of the crop. The application of adequate doses of potassium in vegetable cultures, on the other hand, can help balance the application of $\mathrm{N}$, while offsetting damages.

From the analysis of the substrate used in the experiment, the nutritional requirements of the crop were observed to be $2 \mathrm{~g}^{\text {plant }}{ }^{-1}$ of $\mathrm{N}$; $7.5 \mathrm{~g} \mathrm{plant}^{-1}$ of $\mathrm{P}$ and $2 \mathrm{~g} \mathrm{plant}^{-1}$ of $\mathrm{K}$, considering a stand with 20,000 plants and expected productivity of $20 \mathrm{t} \mathrm{ha}^{-1}$, according to Trani \& Carrijo (2004). As a result, the biofertilizer doses used in this study did not adequately supply the crop's needs (Table 4). Of the three macronutrients, considering the mean dose used, the greater bioavailability was that of potassium, which represented approximately $60 \%$ of the crop's demands, followed by nitrogen with $15 \%$, and phosphorus with only $2 \%$. Therefore, there is a need for much higher doses or supplementation with mineral fertilizer, in the case that the crop is not under organic conditions.
Table 4. Nutrients supplied to the plant for treatment according to the fertilizer recommendation. Fortaleza,Ceará, 2010.

\begin{tabular}{|c|c|c|c|}
\hline \multirow{2}{*}{$\begin{array}{l}\text { Treatments } \\
\left(\mathrm{L} \mathrm{ha}^{-1} \text { week }^{-1)}\right.\end{array}$} & \multicolumn{3}{|c|}{ Amount of nutrients (g/plant) } \\
\hline & $\mathrm{N}$ & $\mathrm{P}_{2} \mathrm{O}_{5}$ & $\mathrm{~K}_{2} \mathrm{O}$ \\
\hline 0 & - & - & - \\
\hline 400 & 0.12 & 0.06 & 0.48 \\
\hline 800 & 0.24 & 0.12 & 0.96 \\
\hline 1200 & 0.36 & 0.18 & 1.44 \\
\hline 1600 & 0.48 & 0.24 & 1.92 \\
\hline \multirow[t]{2}{*}{ Average } & 0.3 & 0.15 & 1.2 \\
\hline & \multicolumn{3}{|c|}{ Amount of nutrients (\%/plant) } \\
\hline 0 & - & - & - \\
\hline 400 & 6 & 0.8 & 24 \\
\hline 800 & 12 & 1.6 & 48 \\
\hline 1200 & 18 & 2.4 & 72 \\
\hline 1600 & 24 & 3.2 & 96 \\
\hline Average & 15 & 2 & 60 \\
\hline
\end{tabular}

\section{CONCLUSION}

The water treatment and the levels of biofertilizers not influence as variable studied. Therefore, in order to establish an adequate crop nutrient supply, further investigative work is recommeded, with the application of higher doses of biofertilizers or even other formulations of this input. Supplementation with chemical fertilizer may work as a second option, although this would not be an acceptable alternative for the standards of organic agriculture.

\section{REFERENCES}

ALLEN, R. G.; PEREIRA, L. S.; RAES, D.;SMITH, M. Crop evapotranspiration - 
guidelines for computing crop water requirements. Roma FAO, 1998.

ANTONIALI, S.; LEAL, P.A.M; MAGALHÃES, A.M.de; FUZIKI, R.T.; SANCHES, J. Physico-chemical characterization of 'Zarco HS' yellow Bell pepper for different ripeness stages. Revista Scientia Agricola, v. 64, p. 19-22, 2007.

ANVISA - AGÊNCIA NACIONAL DE VIGILÂNCIA SANITÁRIA. <Disponível em: http://portal.anvisa.gov.br/wps/wcm/connect/d2 14350042f576d489399f536d6308db/RELAT\% C3\%93RIO+DO+PARA+2009.pdf?MOD=AJP ERES>. Acesso em 02 jul 2011.

AQUATRON. Aquatron Green Machine. Disponível em: <http: //aquatron.com/>. Acesso em: 15 de Abril. 2011.

ARAÚJO, J. A. C. de; FACTOR, T. L.; JÚNIOR, L. V. E. V.; ARAÚJO, J. P. C. de. Utilização do efluente de biodigestor na produção de pimentão em substratos. Revista Horticultura Brasileira, v. 21, p. 371-371, 2003.

ARAÚJO, J. F. Biofertilizantes Líquidos. Juazeiro: Universidade do Estado da Bahia UNEB, 2008. 95 p.

CHARLO, H. C. O; CASTOLDI, R.; FERNANDES, C.; VARGAS, P. F.; BRAZ, L. T. Cultivo de híbridos de pimentão amarelo em fibra da casca de coco. Revista Horticultura Brasileira, v. 27, p.155-159, 2009.

COLLARD, F. H.; ALMEIDA, A.; COSTA, M. C. R.; ROCHA, M. C.; Efeito do uso de biofertilizante Agrobio na cultura do Maracujazeiro Amarelo (Passiflora edulis $f$. flavicarpa Deg). Revista biociências, v. 7, p. 15-21. 2001.

EMBRAPA. Centro Nacional e Pesquisa em Solos. Sistema Brasileiro de Classificação de Solos. Brasilia: Embrapa-SPI; Rio de Janeiro: Embrapa-Solos, 2006. 306 p.

FACTOR, Thiago L.; ARAUJO, Jairo A. C. de, VILELLA JUNIOR, Luiz V. E. Produção de pimentão em substratos e fertirrigação com efluente de biodigestor. Revista Brasileira de Engenharia Agrícola e Ambiental, v. 12, p. 143-149, 2008.

FERREIRA, D. F. Análises estatísticas por meio do Sisvar para Windows versão 4.0. In...45a Reunião Anual da Região Brasileira da Sociedade internacional de Biometria. UFSCar, São Carlos, SP, Julho de 2000. p.255-258.

FILGUEIRA, F. A. R. Solo, nutrição e adubação. IN: Novo Manual de Olericultura.Viçosa: Editora UFV, 2000. p. 4062.

FREIRE, J. L. de O.; CAVALCANTE, L. F.; REBEQUI, A. M.; DIAS, T. J.; NUNES, J. C.; CAVALCANTE, I. H. L. Atributos qualitativos do maracujá amarelo produzido com água salina, biofertilizante e cobertura morta no solo. Revista Brasileira de Ciências Agrárias, v. 5, p. 102-110, 2010.

GRIERSON, D.; KADER, A. A. Fruit ripening and quality. In: ATHERTON, J.G.; RUDICH, J. (eds). The tomato crop: a scientific basis for improvement. London: Chapman Hall. N. 32, p. 241-280, 1986.

PENTEADO, S. R. Cultivo orgânico de tomate. Viçosa, MG: Aprenda Fácil, 214p. 2004.

RIBEIRO, L. G.; LOPES, J. C.; MARTINSFILHO, S.; RAMALHO, L. G. Adubação 
orgânica na produção do pimentão. Revista Horticultura Brasileira, v. 18: p. 134-137, 2000.

SOUSA, M. J. R., MELO, D. R. M. de, FERNANDES, D., SANTOS, J. G. R. dos, ANDRADE, R. Crescimento e produção do pimentão sob diferentes concentrações de biofertilizante e intervalos de aplicação. Revista Verde, v. 4, p. 42-48. 2009.

TRANI, P. E.; CARRIJO, O. A. 2004. Fertirrigação em hortaliças. Campinas: Instituto Agronômico, Série Tecnologia APTA, Boletim Técnico IAC, 196. 53. 